\title{
Effect of Formative and Ability Test Results on Early Learning of Students
}

\author{
Abdul Kadir ${ }^{1}$, Muhammad Ardi ${ }^{1}$, Nurhayati B. ${ }^{1}$ \& Gufran Darma Dirawan ${ }^{1}$ \\ ${ }^{1}$ Environmental Management and Education Program, Makassar State University, Indonesia \\ Correspondence: Abdul Kadir, Environmental Management and Education Program, Makassar State University, \\ Indonesia. E-mail: abdir_edu@yahoo.co.id
}

Received: December 14, 2015 Accepted: January 28, 2016 Online Published: June 28, 2016

doi:10.5539/ies.v9n7p112 URL: http://dx.doi.org/10.5539/ies.v9n7p112

\begin{abstract}
The objective of this study was to examine the relationship of formative tests to early learning ability of students in the science learning style. This research used an experimental method with a 2 x 2 factorial design. The participants comprised all the students in class VII of the Islamic Junior High School State of Kolaka, a total of 343 students from 9 classes. Sampling was based on the use of a two-stage cluster sampling technique to randomly select four classes of students. The four classes were re-randomized, with two being given formative tests and two being given multiple choice tests. The t-test was used to measure the student learning outcomes. The results showed: (1) the use of formative tests in narrative form in the learning process can provide a measure of higher learning output compared with the use of formative multiple choice tests. (2) For those students who have a high initial ability, the use of formative tests can provide higher learning outcomes compared with the use of multiple choice tests. (3) For those students who have a lower initial ability, the use of formative tests in narrative form does not provide a different outcome to tests in multiple choice formats.
\end{abstract}

Keywords: formative test form, early ability and learning outcomes science

\section{Introduction}

Education is the key to progress and development of the people and communities throughout Indonesia, because with education human resources may evolve in a more positive direction. In order to develop quality human resources, people have to go through the process of learning through education. Learning is a system in which the elements are interrelated and interact with each other.

Success in learning is determined by the skills of teachers in choosing or applying appropriate methods and learning strategies for students. Students interact to their learning activities in a variety of ways, based on the nature of the task and their preferred way of learning. However, the selection and use of appropriate learning methods is still a potential obstacle for some students. As described by Sumedi (2002), generally students use learning methods that are less precise, making it impossible for them to maximize the mastery of knowledge and skills within the context of their learning objectives.

The inability of students to master their learning objectives is one of the causes of their poor learning outcomes. One indicator of this poor outcome is in the poor test scores achieved in formative science subjects in the Islamic Junior High School State of Kolaka, where the average score achieved by students is $68.21 \%$, while the minimum score set by science teachers for completion of studies is $70.00 \%$.

The above data shows indicate that the success rate of students in classified science subjects is relatively low. A main contributing factor to the low level of student learning outcomes is believed to be related to the choice of inappropriate learning strategies. However, this problem is rarely addressed by educational researchers. Therefore, this paper examines one aspect of learning strategies, this being the initial capabilities of the students before receiving lessons. It is alleged that the learning ability of students is one indicator of the potential outcome/success of student learning.

One of the instruments used to determine the quality of learning outcomes and also to encourage students learning activities is formative evaluation. Frequent formative evaluation in the learning process can be reflected in improved students' learning outcomes. As described by Badger (2002, p. 5) 'testing can encourage students' learning activities" and there should be at least two objectives: increasing the understanding and repetition 
frequency of lessons, and knowing that the materials taught are understood in learning". Tests carried out can also provide important information for teachers, especially in terms of helping with the focus of learning, and in providing evidence of student understanding. To make valid and reliable judgments about the level of student achievements, teachers should use a variety of approaches and evidence for the measurement of the impact of learning approaches.

Instruments used in educational assessment can be a test, for example descriptions and multiple-choice tests, and/or non-test instruments such as scales, observations, and interviews. Test description requires students to formulate problems, think of solutions, interpret, and express opinions in writing (Popham, 1995, p. 70). Multiple choice tests are aimed to check the students' knowledge of certain concepts and skills (Wiesma \& Jurs, 1990, p. 49).

Realizing the importance of prior knowledge of the students and conjecture about the ability of the students in response to test items which are influenced by their prior knowledge, this study assessed a formative influence on the test results in terms of the ability to learn science of beginning students.

The general objective of this study was to determine the influence of the shape of formative tests used in the evaluation of the learning process and ability on the learning outcomes of students in science subjects. Operationally, these objectives are described as follows. The first test was for differences in learning outcomes of students who were given science subject tests in formative forms in comparison with students who were given a description formative multiple choice test. The second test was on the differences in learning outcomes of students in science subjects among students who have a high initial capability based on the formative test form in comparison with the students who were given descriptive formative multiple choice tests. A third test for focused on the differences in learning outcomes of students in science subjects among students with lower initial ability based on tests formative form students who were given a descriptive formative multiple choice test, and the interaction between the shape of formative tests with ability the beginning of the learning outcomes of students.

\section{Research Approach}

This study uses quantitative methods with experimental approaches at the Kolaka State Islamic Junior High School. The study was undertaken between April to June 2014. In this experimental study put: (1) the intensity of formative assessment (treatment variable) as the independent variables treatment; (2) science learning outcomes with a numeric data scale as the dependent variable (criterion variable); and (3) the ability in early science, with a numerical scale consisting of two levels (high and low ability) as variable attributes. The design of this experiment was a $2 \times 2$ factorial design, (Borg \& Gall, 1983, p. 679).

The population was seventh grade students in the Islamic Junior High School State of Kolaka which consists of 9 parallel classes with a total 343 students. The determination of samples was based on the use of a two-stage cluster sampling technique (Suwanda, 2011, p. 145). Respectively, four classes were randomly selected from the 9 parallel classes available. The four classes were re-randomized into two groups, with two classes for formative test group which was given a description test and two classes for the group was given a multiple choice test. The instruments and data collection techniques used in this study were as follows: Tests in the form of questions that had to be answered by the students to determine learning outcomes achieved. The test was in the form of written questions shaped to the description, and multiple-choice tests with the aim of collecting data science learning outcomes for students who were known to have low and high levels of knowledge. The research instrument used was in the form of science achievement test which was first tested for its validity and reliability. Data analysis techniques were used for descriptive and inferential statistical analysis. Inferential analysis which should be at the start with the following test analysis requirements: Kolmogorov-Smirnov test for normality testing and homogeneity testing, using Levene's Test of Equality of Error Variances. In testing the hypothesis, Analysis of Variance (Two Way Anova) was used, with t-tests for testing the average value of student learning outcomes, (Kadir, 2010:107).

\section{Results}

\subsection{Descriptive Analysis Results}

A description of the results of the learning of students who have the ability (high and low) is given treatment form of formative tests (multiple choice and essay) is presented in Table 1 below. 
Table 1. Description of data values of learning outcomes of science formative tests given to students initial control capabilities

\begin{tabular}{lcccc}
\hline \multirow{2}{*}{ Statistics } & \multicolumn{4}{c}{ Essay test results and Early Ability Results of the tests are multiple choice and ability Early } \\
\cline { 2 - 5 } & High & Low & High & Low \\
\hline Mean & 83.7222 & 75.8889 & 81.6667 & 76.1111 \\
Median & 83.5000 & 76.0000 & 80.0000 & 75.0000 \\
Mode & 78.00 & 75.00 & 80.00 & 75.00 \\
Std. Deviation & 7.18574 & 4.66463 & 6.21059 & 5.98941 \\
Variance & 51.635 & 21.759 & 38.571 & 35.873 \\
Maximum & 100.00 & 85.00 & 95.00 & 85.00 \\
Minimum & 70.00 & 65.00 & 70.00 & 65.00 \\
Range & 30.00 & 20.00 & 25.00 & 20.00 \\
\hline
\end{tabular}

\subsection{Results of Testing Requirements Analysis}

Before testing the hypothesis, an analysis of pre-requisite tests was conducted, including a normality test and homogeneity test, each of which used Kolmogorov Smirnov (KS) to test for normality, while the Levene test was used to test for the homogeneity of the variance test. The results of calculations based on the use of Statistical Product and Service Solutions (SPSS version 21) are as follows:

3.2.1 Normality Test

Table 2. Summary of research data normality test results

\begin{tabular}{llll}
\hline Data group & Probability Value $(\rho)$ & Sig. & Conclusion \\
\hline$A_{1} B_{1}$ & 0.237 & & Normal distribution \\
$A_{1} B_{2}$ & 0.890 & $\alpha=0.05$ & Normal distribution \\
$A_{2} B_{1}$ & 0.733 & & Normal distribution \\
$A_{12} B_{2}$ & 0.404 & & Normal distribution
\end{tabular}

Criteria: If the probability is $(\rho)>0.05$, then $\mathrm{H}_{0}$ is accepted and it is concluded that the value of residual (error) has a normal spread. If the probability $(\rho)<0.05$ then $\mathrm{H}_{0}$ is rejected and it would be concluded that the value of residual (error) does not have a normal spread.

\subsubsection{Variance Homogeneity Test}

Table 3. Summary of results of testing homogeneity of data research

\begin{tabular}{lccccc}
\hline \multicolumn{5}{c}{ Test of Homogeneity of Variances } \\
\hline \multicolumn{5}{c}{ Variance group Levene Statistic df1 df2 Sig. ( $\rho$ ) } & Conclusion \\
\hline $\mathrm{A}_{1} \mathrm{~B}_{1}$ and $\mathrm{A}_{1} \mathrm{~B}_{2}$ & 1.025 & 5 & 30 & .421 & Homogeneous \\
$\mathrm{A}_{2} \mathrm{~B}_{1}$ and $\mathrm{A}_{2} \mathrm{~B}_{2}$ & 2.424 & 8 & 24 & .630 & Homogeneous \\
$\mathrm{A}_{1} \mathrm{~B}_{1}$ and $\mathrm{A}_{2} \mathrm{~B}_{1}$ & .892 & 5 & 30 & .499 & Homogeneous \\
$\mathrm{A}_{1} \mathrm{~B}_{2}$ and $\mathrm{A}_{2} \mathrm{~B}_{2}$ & 2.247 & 9 & 24 & .549 & Homogeneous
\end{tabular}

Criteria: If the value of $\rho>\alpha=0.05$ this means that the data is spread homogeneously and vice versa if $\rho<\alpha=$ $0.05=$ data is not homogeneous spread. 


\subsubsection{Hypothesis Testing Results}

Results data study science students Islamic Junior High School State of Kolaka that has been collected, and then conducted testing of hypothesis. A summary of the results of hypothesis testing presented in Table 4.

Table 4. Summary of the results of hypothesis testing two way Anova

\begin{tabular}{ccccccc}
\hline Effect of Variance & Sum of Squares & $\mathrm{Dk}$ & Means Square & $\mathrm{F}_{\mathrm{h}}$ & $\mathrm{F}_{\mathrm{t}}$ & Sig. $(\rho)$ \\
\hline Forms of formative tests (A) & 24.174 & 1 & 24.174 & 6.393 & 3.059 & .042 \\
Initial capability (B) & 1813.903 & 2 & 906.951 & 23.984 & 3,060 & .000 \\
Interaction (AxB) & 47.840 & 1 & 47.840 & 11.403 & 3.059 & .231 \\
Total & 912643.000 & 144 & & & & \\
\hline
\end{tabular}

Criteria: Significance level $(\alpha)=0.05$;

a. If $\mathrm{F}_{\text {count }}<\mathrm{F}_{\text {table }}$, then $\mathrm{H}_{0}$ is accepted and if $\mathrm{F}_{\text {count }}>\mathrm{F}_{\text {table }}$, then $\mathrm{H}_{0}$ is rejected;

b. If sig $>0.05$ then $\mathrm{H}_{0}$ is accepted and if sig $<0.05$ then $\mathrm{H}_{0}$ is rejected.

The presence of interactions and significant main effect (main effect) between columns and rows in the analysis of variance between the above test is followed by Tukey's test for determining the average of a data group, whichever is higher between the two data sets are compared. Tukey test results are summarized in Table 5.

Table 5. Summary of results of testing t-test

\begin{tabular}{ccccc}
\hline No. & Groups compared & t-test & t-table & Sig $(\rho)$ \\
\hline 1 & $\mathrm{~A}_{1}$ and $\mathrm{A}_{2}$ & 2.621 & 1.994 & .011 \\
2 & $\mathrm{~A}_{1} \mathrm{~B}_{1}$ and $\mathrm{A}_{2} \mathrm{~B}_{1}$ & 5.110 & 2.030 & .000 \\
3 & $\mathrm{~A}_{1} \mathrm{~B}_{2}$ and $\mathrm{A}_{2} \mathrm{~B}_{2}$ & 6.337 & 2.030 & .000 \\
\hline
\end{tabular}

Criteria: Significance level $(\alpha)=0.05$;

a. If the $\mathrm{t}_{\text {count }}<\mathrm{t}_{\text {table }}$, then $\mathrm{H}_{0}$ is accepted and if the $\mathrm{t}_{\text {count }}>\mathrm{t}_{\text {table }}$, then $\mathrm{H}_{0}$ is rejected;

b. If $\operatorname{sig}>0.05$ then $\mathrm{H}_{0}$ is accepted and if $\operatorname{sig}<0.05$ then $\mathrm{H}_{0}$ is rejected.

Based on the summary of the results of analysis presented in Table 5, the results of hypothesis testing (t-test) can be summarised as follows:

1) The results of the first hypothesis testing; Value $t_{\text {count }}=2.621$, and the $t_{\text {table }}=1.994$ at significance level of $5 \%$. If the value of $\mathrm{t}_{\text {count }}$ compared to the $\mathrm{t}_{\text {table }}$ value obtained $\mathrm{t}_{\text {count }}>\mathrm{t}_{\text {table }}$, and a probability value (Sig) 0.011 $<\alpha=0.05$, then Ho is rejected, meaning that the science student's learning outcomes for students given the formative test are higher than for the use of formative multiple choice tests in Islamic Junior High School State of Kolaka. This means that there are potentially significant differences between students' science learning outcomes based on the choice of the formative test vs the multiple choice test for the students at this school.

2) The results of testing the second hypothesis are: Value $t_{\text {count }}=5.110$, while the $t_{\text {table }}=2.030$ at significance level of $5 \%$. If the vallue of $\mathrm{t}_{\text {count }}$ compared to the $\mathrm{t}_{\text {table }}$ value obtained $\mathrm{t}_{\text {count }}>\mathrm{t}_{\text {table }}$ and a probability value (Sig) $0.000<\alpha=0.05$, then Ho is rejected. This means that the science learning outcomes based on the tests in the formative form provide a better description of the results of students' science learning than the formative multiple choice tests. This means that there are significant differences between students' science learning outcomes dependent on the use of the formative tests vs the multiple choice test, with students in the Islamic Junior High School State of Kolaka.

3) The third hypothesis test results; Value $\mathrm{t}_{\text {count }}=6.337$, while the $\mathrm{t}_{\text {table }}=2.030$ at significance level of $5 \%$. If the value of $\mathrm{t}_{\text {count }}$ compared to the $\mathrm{t}_{\text {table }}$ value obtained $\mathrm{t}_{\text {count }}>\mathrm{t}_{\text {table }}$ and a probability value of $0.000<\alpha=0.05$, then $\mathrm{H}_{0}$ is rejected, meaning that the science student learning outcomes for students with a low initial capability based on formative tests in narrative form are lower than for students who were given a test in 
the formative multiple choice form, in Islamic Junior High School State of Kolaka. This means that there are significant differences between students science learning outcomes for students given tests in narrative form vs tests in formative multiple choice form for students assessed as having high and low initial capabilities in Islamic Junior High School State of Kolaka.

\section{Discussion}

First, the research hypothesis which states that science learning outcomes of students who are given the test in the formative narrative form are higher than for students who were given a formative multiple choice test, turns out empirically correct based on the data. This finding may be explained further by comparing the characteristics of both forms of the tests. Based on the data measured learning outcome, then the form of multiple choice tests are very effective for measuring low-level cognitive abilities, but was less effective for measuring high-level cognitive abilities. However, the test in narrative form is less effective for measuring low-level cognitive abilities, effective for measuring moderate cognitive abilities moderate and very effective to the measurement of high-level cognitive abilities. Judging from the range of materials, The multiple choice test covers extensive material and allowing it to represent a broad base of material, while the test in narrative is descriptive and focused on a rather narrow a narrow range of material. Other factors that affect the participants test scores in the multiple choice test include the ability to read and guess. The multiple choice tests can also, encourage students to recall, interpret, and consider the ideas of others.

The study of science should involve comprehensive thought (deductive and inductive), the ability to use statistical analysis and applied mathematics, observation, investigation patterns, as well as the ability to link physical and social symptoms to the objectives of science. These characteristics are able to be assessed by tests in narrative form. A fact which supports the above reasons that turned out to be the achievement of the average science student learning outcomes in the delivery of formative tests in narrative form higher than the provision of formative tests multiple choice form a double. This is empirical evidence that treatment with the administration of formative tests in narrative form is more effective in improving students' science learning outcomes compared to treatment with the administration of formative multiple choice test. This finding is in line with the characteristics of each form of the test as described. Thus, the hypothesis put forward unsubstantiated. Thus giving formative tests in narrative form continuously to measure student learning outcomes will encourage improving student learning outcomes compared with formative multiple choice test.

Second, the research hypothesis which states that science student learning outcomes among students who have a high initial capabilities by test formative narrative form higher than students who were given a formative test multiple choice form, it turns out empirically proven by the data. If the initial ability of students associated with the test description form used in formative evaluation, then the characteristics of high initial capability in accordance with the description of the characteristics of the test form harmonious take steps in problem solving, the ability to organize ideas, compare, apply formulas, differentiate, analyze, evaluate, make inferences, develop problem-solving solutions.

Explains the principles of psychological and explain the causal relationship. It is important that the test form of description can give more feedback to the students who in turn will improve the quality of student learning to the maximum. Test description form providing the freedom to express their thoughts and ideas so as to encourage students to express opinions with a more in-depth description and suggests things that are principle so as to optimize the quality of the answers.

Freedom of expression is also needed to measure learning more complex such as analysis, synthesis and evaluation. Freedom to express themselves in an opinion to answer any questions in narrative form also can improve students' motivation in harmony with the objectives to be achieved in order to encourage early abilities of the students before accepting learning.

Some characteristics of the test forms above description when compared with the characteristics of students who have a high initial ability, the students with high initial ability can respond formative test well in narrative form. Outlined characteristics above also shows, that the test form of description is a form of test that requires deep thought in answer. It means that the characteristics of the test in accordance with the characteristics of the narrative form students who have a high initial capability is the effort that is autonomous in achieving academic competence, like structured task analytical cognitive, analyze a problem until well organized, and specific thinking.

A fact which supports some of the statements above show that the average achievement of learning outcomes teaching science students who have a high initial ability and formative tests given in narrative form higher than students who were given a formative test multiple choice form. This finding is in line with the characteristics of 
high initial capabilities and characteristics of the test in narrative form. Thus, students who have a high initial capability by tests formative shape to obtain a description of learning outcomes of science is higher than the students who were given a formative test multiple choice form.

Third, the research hypothesis which states that science learning outcomes of students who have the ability to lower initial formative tests given in narrative form lower than students who were given a formative test multiple choice form, it turns out empirically proven by the data. This happens because generally students who have a low initial capabilities: (1) Lack of initiative in learning, more like learning program has been structured and follow a learning program whose goal has been clearly defined. (2) Preferred learning study materials has been clearly determined, ways of learning have also been clearly determined. Highly dependent on the guidance and explanation from the teacher, always feel worried that his interpretation of the content is less precise, because it is an explanation of the teacher is considered very important. Students like these tend to be on their own, before asking for help from others. (3) There can assess their own capabilities, preferred learning program that has had clear success criteria, so as to direct the learning activities to achieve these criteria.

The characteristics of students who have lower initial ability is highly dependent on external motivation and lack of initiative in learning, more like learning program has been structured, and follows the learning program objectives are clearly defined, and highly dependent on teacher learning. While the characteristic form of formative tests compared with the narrative form is a multiple choice test, test description form has several characteristics that distinguish it from the multiple-choice test, which can encourage students to organize ideas, compare, discriminate, judge, make inferences, develop problem-solving solutions, explains psychologically and explain the principle of causality. In addition, the test form of description does not provide many opportunities for students to speculate and chancy, and encourage students to dare to express their opinions in writing.

Test description form can give more feedback to students, and can enhance students' learning activities, which in turn leads to an increase optimal learning result. Although the test is more difficult than in narrative form with multiple choice test, but if associated with the presence of students who have lower initial ability seems to result from a lack of initiative in learning, is highly dependent on external motivation, more like learning program has been structured, and follows the learning program whose purpose has been clearly formulated, and highly dependent on teacher learning, then students are thus not motivated enough by providing formative test multiple choice or narrative form.

This means that any form of formative tests given to students who have the ability to lower initial result remains the same. Thus, quite groundless to reject the hypothesis that "science subjects learning outcomes of students who have the ability to lower initial formative tests given in narrative form lower than students who were given a formative test multiple choice form". Which means at the level of the initial ability low, the use of formative tests in narrative form and did not give a multiple-choice science learning outcomes are different.

Thus the measurement and assessment of student learning outcomes is an integral part of learning. Assessment is not only used to collect data, but also to identify learning needs and learning difficulties. Described by Gronlund $(1985$, p. 8) that the assessment in the learning process aims to: (1) preparing the expected learning objectives; (2) determining learning needs; (3) monitor the development and learning difficulties; and (4) assessing the learning outcomes achieved. This means that the development and application of quality assessment instruments in the measurement of student learning outcomes also serves to influence the quality of learning.

In addition to the use of evaluation tools in the form of descriptions and multiple-choice tests, also alleged that one of the factors that affect student learning outcomes is the ability of the students before the beginning of the learning gain. High or low initial ability of the students are expected to be able to affect the quality of student learning outcomes. According to Dick and Carey (2005), prior knowledge is knowledge or skill that has been owned by the students before following subjects will be given. With prior knowledge students can learn the material that will be taught by teacher and vice versa without the prior knowledge students will have difficulty studying the subject matter further.

Opinions above gives and explanation that the teacher in choosing the use of appropriate forms of formative tests must consider the initial ability of students, because every student has the ability to start different. Therefore, early identification of students' ability to be very important in the management of learning, so the implementation of formative assessment in the eyes learning science can be adjusted based on the level of prior knowledge of students.

\section{Conclusions}

Based on the test results and discussion of the results of the study, the following conclusions are made in relation 
to the learning process for science subjects by students of class VII in the Islamic Junior High School State of Kolaka.

(1) The use of formative tests in narrative form in the learning process can provide higher learning results compared to the use of formative multiple choice tests.

(2) For students who have a high initial ability, the use of formative test essay form in the formative evaluation can provide a learning outcome is higher than with the use of formative multiple choice test.

(3) For students who have a lower initial ability, the use of formative multiple choice tests provide better learning outcomes compared with use of the test essay form.

\section{Acknowledgements}

Gratitude is acknowledged to the Environmental Education Program, Post Graduate School, Makassar State University.

\section{References}

Badger, E. (2002). Open-Ended Questions in Reading. Massachusetts Department of

Borg, W. R., \& Gall. M. D. (1983). Educational Research. New York \& London: Longman.

Dick, Walter, \& Lou Carey. (2005). The Systematic Design of Instructional Third Education. Boston: Pearson.

Gronlund, N. E. (1985). Measurement and Evaluation in Teaching (5th ed.). New York: Macmillan Publishing Company.

Kadir. (2010). Statistika Untuk Penelitian Ilmu-Ilmu Sosial. Jakarta: Rosemata Sampurna.

Popham, W. J. (1995). Classroom Assessment, What Teachers Need to Know. Needham Heights: Allyn and Bacon, A Simon \& Schuster Company.

Sumedi, P. (2002). Mengenal Belajar Siswa untuk Mengatasi Kegagalan. Jakarta: Universitas Terbuka.

Suwanda, (2011). Duraiann Eksperimen untuk Penelitian Ilmiah. Bandung: Alfabeta.

Wiersma, W., \& Jurs, S. G. (1990). Educational Measurement and Testing. Massachusetts: Allyn \& Bacon.

\section{Copyrights}

Copyright for this article is retained by the author(s), with first publication rights granted to the journal.

This is an open-access article distributed under the terms and conditions of the Creative Commons Attribution license (http://creativecommons.org/licenses/by/3.0/). 